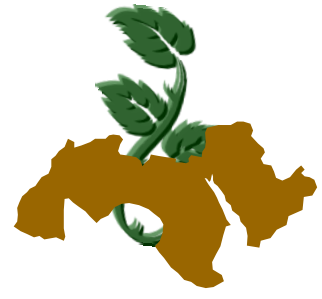

Arab Univ.

J. Agric. Sci., Ain Shams Univ., Cairo, 18(1), 155-163, 2010

\title{
UTILIZATION OF ACEROLA FRUIT AS A SOURCE OF POWERFUL ANTIOXIDANT FOR ENRICHMENT OF SOME PROCESSED FOODS
}

\author{
Abd El-Malak', G.A.; Zeinab M. Hamdy² and H.M. Radwan' ${ }^{1}$ \\ 1- Crops Horticultural Processing Research Department, Food Technology Research Institute, \\ Agricultural Research Center, Giza, Egypt \\ 2- Horticultural Research Institute, Agricultural Research Center, Giza, Egypt
}

[12]

Keywords: Acerola, Ripening stages, Drying, Phytochemical compounds, Jam

\begin{abstract}
Four stages of maturity acerola fruits (Malpighia glabra L.) namely green, mature green/yellow, pale red and ripe mature were analyzed in fresh and dried at $50^{\circ} \mathrm{C}$ under vacuum. Also, fresh fruits were used to prepare jam and mixed with different ratios of fig fruit. Results showed that protein content was gradually decreased from 1.12 for green to $0.82 \%$ for ripe mature stage of acerola, while, the titratable acidity was decreased gradually with increasing the maturity stage while, the $\mathrm{pH}$ and soluble solids were gradually increased. The highest percentages of reducing and total sugars were observed for pale red stage and the lowest were showed in green stage. Also, ascorbic acid was higher in green/yellow mature while in pale red and ripe stages were lower. Phenolic compounds were analyzed by HPLC in acerola fruit. The detected phenolic compounds were gallic, protocatechuic, catchein, catechol, chlorogenic, caffeic, syringic, ellagic, ferrulic, coumarine and cinnamic in both fresh and dried acerola. The green/yellow maturity of acerola extract recorded the highest percent of total antioxidant activity $(74.46 \%)$ while the lowest total antioxidant activity was observed in the ripe mature acerola $(20.75 \%)$. Sensory evaluation of jam prepared from acerola and mixed with fig 1:1 recorded the highest scores compared to other prepared jams. Meanwhile, the content of ascorbic acid and total antioxidant activity were increased by increasing the percent of acerola fruit.
\end{abstract}

\section{INTRODUCTION}

Acerola (Malpighia glabra L.), originally from Antilles, was cultivated in Brazil nowadays, the major worldwide producer, consumer and exporter Vera de Rosso et al (2008).

Acerola, also known as cherry in West Indian, Barbados cherry or Antilhas Cherry (Malpighia glabra L., Malpighia punicifolia L. or Malpighia emarginata $D C$.) and grows also in the northeast of South America and in Central America. It is round shape, with diameter varying from 3 to $6 \mathrm{~cm}$. Its fleshy and succulent pulp surrounded by a very thin protection peel which helps for quickly ripening. At the initial stage of ripening, the fruit is a full green color, changing to yellow-reddish and finally to red or purple when completely ripened (Assis et al 2001).

Acerola rich in other nutrients such as carotenes, thiamin, riboflavin, niacin, proteins, and mineral salts, mainly iron, calcium and phosphorus (Assis et al 2001). The composition of acerola fruit depends on some factors such as climatic conditions, the culture treatments and geographic location also stage of maturation or processing and storage Hanamura et al (2005).

Nowadays, Acerola plants were introduced to Egypt through Horticulture research institute, Agricultural Research Center in September, 2003. Acerola is a potential crop in Egypt which has perfectly environmental conditions climate and soil appropriate for the acerola culture and also need to low water requirement, low labor input and low crops management.

Acerola is recognized as a functional food due to its main appealing feature as high Vitamin C content, which might vary from 1247.10 to 1845.79 $\mathrm{mg} / 100 \mathrm{~g}$ (Lima et al 2005); the consumption of 
three fruit units for an adult per day satisfies the recommended dietary allowance of vitamin C. (Mezquita and Vigoa, 2000).

The Vitamin $\mathrm{C}$ contents in the concentrated immature, the immature, and the mature acerola juices were $4.80,1.90$ and $0.97 \mathrm{~g} / 100 \mathrm{~g}$ for respectively. While, the total phenol contents decreased during ripening, from $3.8 \mathrm{mg}$ of catechin $/ \mathrm{g}$ for immature acerola juice to $1.4 \mathrm{mg} / \mathrm{g}$ for mature acerola juice. The concentrated immature juice had a content of $9.2 \mathrm{mg} / \mathrm{g}$ of juice (Righetto et al 2005).

The physico-chemical characteristics of mature acerola fruits contained total anthocyanins from 3.81 to $47.4 \mathrm{mg} / 100 \mathrm{~g}$ of pulp, total flavonols from 7.00 to $18.5 \mathrm{mg}$ quercetin/ $100 \mathrm{~g}$ pulp, titratable acidity (TA) from 1.04 to $1.87 \mathrm{~g}$ of malic acid/ $100 \mathrm{~g}$ of pulp, total soluble solids from 7.00 to 8.43 Brix/ TA ratio from 4.36 to 6.86 and $\mathrm{pH}$ from 3.11 to 3.41 (Lima et al 2005).

Recently, much attention has been paid to their content in carotenoids and bioflavonoids for their antioxidant properties. Carotenoids are present at levels between 3.2 and $406 \mathrm{mg} / \mathrm{kg}$ (Lima et al 2005). Mezadri et al (2005) found that, acerola contained highest content of $\beta$-carotene was (40$60 \%$ of total carotenoids). The main components of acerola fruit from flavonoids are anthocyanins $(3.79-59.74 \mathrm{mg} / 100 \mathrm{~g})$ and flavonols (7.0-18.5 $\mathrm{mg} / 100 \mathrm{~g}$ ) (Mezadri et al 2008). Besides the colorant property, (Seeram \& Nair, 2002) found that the anthocyanins have the colorant property and also as an exhibit potential therapeutic effect for antiinflammatory, radiation-protective, chemoprotective, vasoprotective, inhibition of LDL oxidation and decrease the risks of cardiovascular diseases.

The association between the consumption of fruit and vegetables affects for reducing the risk of cardiovascular disease and cancer which are supported by considerable epidemiological evidence (Hertog et al 1995 and WHO, 2003). This beneficial effect is due to the action of antioxidant compounds, which are capable of neutralizing free radicals and reduce oxidative damage in the body (Clifford, 1995).

The low stability of the acerola anthocyanins represents a problem during the storage of the pasteurized juice and frozen pulp of this fruit. The presence of ascorbic acid (AA) has shown a negative impact on anthocyanin stability, leading to the mutual degradation of these compounds (Garzon \& Wrolstad, 2002 and Brenes et al 2005).

The aim of this study is to determine the content of natural antioxidants of acerola such as vitamin $\mathrm{C}$, total carotenoids and anthocyanin at dif- ferent maturity stages for fresh and dried acerola, as well as to evaluate the polyphenols compounds by using HPLC which also considered as effective antioxidant. The acerola fruit behavior and quality attribute of jams prepared with mixing of acerola and fig fruit was also undertaken.

\section{MATERIALS AND METHODS}

\section{1- Sample preparation}

Acerola fruits (Malpighia glabra L.) at different maturity stages were carefully harvested from plants grown in Horticulture research institute, Agriculture research center, Giza, Egypt at season 2008 in March and April. Twenty kilograms of sampling acerola fruit were divided to four mature stages first stage (green), second (mature green/yellow), third (pale red) and fourth (ripe mature). These samples were performing to dried or used as fresh then press crushing. Care was taken to have homogeneity in each lot. Once harvested, the fruits were frozen and stored at $-18{ }^{\circ} \mathrm{C}$ until analysis was performed. Then they were unfrozen and immediately dried at $50^{\circ} \mathrm{C}$ under vacuum.

\section{2- Preparation of mixed jam}

One kilogram of jams was prepared by mixing acerola fruit pulp and fig fruit 1:1 and $1: 2$ and sucrose was added 1:1 W/W then homogenized and cooked in stainless vessel until $60 \%$ of dry matter was achieved.

\section{3- Sensory evaluation}

The sensory evaluations of acerola jam were carried out with three replications by 10 trained panelists. The quality attributes of acerola jam were organized into flavour (odour and taste), texture, colour and over all acceptability. All organized attributes were scored between 0 (the worst) and 10 degree.

\section{4- Chemical analysis}

Moisture, protein, ash, titratabe acidity, $\mathrm{pH}$, reducing sugar, non reducing sugar and total sugars were determined according to AOAC (1990).

Total soluble solids were determined by using refractometer at $\sim 25^{\circ} \mathrm{C}$ and the result expressed as Brix.

Pectin was determined according the method described by Shelukhina and Fedichkina (1994). Determination of phenolic compounds 
Extraction, separation and quantification of phenolic compounds were determined according to the method described by Goupy et al (1999).

\section{Determination of total antioxidant activity of acerola}

Antioxidant activity was determined according to the method of Brand-Williams et al (1995) and modified by Zhang \& Hamauzu (2004) as follows: Five grams of acerola fruit pulp at different ripening stages was extracted by $100 \mathrm{~mL} 80 \%$ methanol. Different concentrations 10 to $50 \mu \mathrm{mL}$ were used to determine the percents of antioxidant activity using 2, 2-diphenyl-1picryl hydroxyl (DPPH) purchased from Sigma Co.

Total phenolics were estimated with the method described in (AOAC 1970) by using photometric method with folin's reagent.

Flavonoids were extracted and determined according Zhuang et al (1992).

Carotenoids and ascorbic acid were determined according to (AOAC 1990).

Total anthocyanins were determined according to the method described by Colin and Peter (1980).

\section{5- Statistical analysis}

All data were recorded as means and analyzed by SPSS Windows (ver.10.1.). One-way analysis of variance (ANOVA) and Duncan comparisons were tested to signify differences between raw and different treatments of acerola.

\section{RESULTS AND DISCUSSION}

Results in Table (1). Shows the chemical composition of acerola fruit at different stages of maturation (green, green/yellow, pale red, ripe mature). Protein content was gradually decreased from 1.12 for green to $0.82 \%$ for ripe mature. No significant decrease in ash content was observed at different maturity stages of acerola from green to ripe mature. Meanwhile, the titratable acidity was gradually decreased with increasing maturity stages of acerola from $14.17 \%$ for green mature stage to $8.00 \%$ in ripe mature, calculated with $\mathrm{NaOH} 0.1 \mathrm{~N} / 100 \mathrm{~g}$ of fresh acerola, On the other hand, the $\mathrm{pH}$ and soluble solids were gradually increased with increasing the maturity stage. Where, the TSS were 7.99 in green, 8.44 in green/yellow, 8.83 in pale red and 8.21 in ripe mature while $\mathrm{pH}$ ranged from 3.03 to 3.27 , respectively. The highest reducing and total sugars were observed with green/yellow stage of acerola. The corresponding results were 2.72 and $4.3 \%$. Meanwhile the lowest percentages of both reducing and non reducing sugars were in green stage, 1.63 and $2.32 \%$, respectively. Results also show that the pectin content was $0.49 \%$ in the green stage and decreased to $0.32 \%$ through increasing the maturity stages.

The phytochemical compounds in fresh acerola in comparison with dried acerola are shown in Table (2). Results reveal that the contents of ascorbic acid in green, green/yellow, pale red and ripe mature was observed 1430, 1568.67, 1317.33 and $842.16 \mathrm{mg} / 100 \mathrm{~g}$, respectively calculated on fresh weight. However the highest content of ascorbic acid was observed in (green/yellow), but decreased in ascorbic acid was observed in ripe mature. Ascorbic acid was greatly reduced from the green to the red fruit with a loss of about $50 \%$ due to the biochemical oxidation. This is supported by the appearance of 3-hydroxy-2-pirone which was found only in ripe acerola as result of the oxidative breakdown of ascorbic acid. (Vendramini \& Trugo, 2000). The corresponding contents of ascorbic were 552.66, 582.92, 547.09 and 366.82 after drying acerola at $50^{\circ} \mathrm{C}$ under vacuum, respectively, while phenols and flavonoid contents had the highest content in green/yellow stage. The content of both phenols and flavonoids were 2935.5 and $14.21 \mathrm{mg} / 100 \mathrm{~g}$, while the lowest content was 2259.99 and $10.88 \mathrm{mg} / 100 \mathrm{~g}$ which showed in ripe mature stage. Both phenols and flavonoids content were significantly decreased to 25.17 and $26.56 \%$ in (green), 21.68 and $19.35 \%$ in (green/yellow), 22.37 and $26.82 \%$ in (pale red) and 27.53 and $34.19 \%$ in (ripe mature). Carotenoids content was determined and the results are illustrated in Table (2). The total Carotenoids content was increased by increasing the maturity stage. The total carotenoids content ranged from $1010.1 \mu / 100 \mathrm{~g}$ in green stage increased to $1924.0 \mu / 100 \mathrm{~g}$ in ripe mature stage while, these contents were decreased to 745.6 and $1467.05 \mu / 100 \mathrm{~g}$, respectively after drying samples. On the other hand, total anthocyanins was drastically increased from 2.1 in green acerola to $14.79 \mathrm{mg} / 100 \mathrm{~g}$ in ripe mature stage of acerola and the corresponding contents were decreased after drying of acerola to 1.07 and $5.36 \mathrm{mg} / 100 \mathrm{~g}$, respectively. The rich of acerola fruits in these phytochemical compounds play an important role as a beneficial healthy effect owing the action of antioxidant compounds, which are capable of neutralizing free radicals and reduce oxidative damage in the body (Clifford, 1995). 
Table 1. Chemical composition of acerola at different maturity stages depending on colour

\begin{tabular}{|l|c|c|c|c|}
\hline & green & green/yellow & pale red & ripe matue \\
\hline Moisture & $88.12 \mathrm{c}$ & $89.22 \mathrm{~b}$ & $9.04 \mathrm{a}$ & $90.21 \mathrm{a}$ \\
Protein & $1.12 \mathrm{a}$ & $1.07 \mathrm{a}$ & $0.95 \mathrm{~b}$ & $0.82 \mathrm{c}$ \\
Ash & $0.54 \mathrm{a}$ & $0.53 \mathrm{a}$ & $0.53 \mathrm{a}$ & $0.52 \mathrm{a}$ \\
Titratabe acidity * & $14.17 \mathrm{~b}$ & $15.67 \mathrm{a}$ & $9.5 \mathrm{c}$ & $8 \mathrm{~d}$ \\
pH & $3.03 \mathrm{~b}$ & $3.1 \mathrm{ab}$ & $3.18 \mathrm{ab}$ & $3.27 \mathrm{a}$ \\
Soluble solids & $7.99 \mathrm{~b}$ & $8.44 \mathrm{ab}$ & $8.83 \mathrm{a}$ & $8.21 \mathrm{~b}$ \\
Reducing sugar & $1.63 \mathrm{~d}$ & $2.32 \mathrm{~b}$ & $2.72 \mathrm{a}$ & $1.76 \mathrm{c}$ \\
Non-reducing sugar & $0.69 \mathrm{~d}$ & $1.88 \mathrm{a}$ & $1.58 \mathrm{~b}$ & $1.37 \mathrm{c}$ \\
Total sugar & $2.32 \mathrm{c}$ & $4.2 \mathrm{a}$ & $4.3 \mathrm{a}$ & $3.13 \mathrm{~b}$ \\
Pectin & $0.49 \mathrm{a}$ & $0.41 \mathrm{~b}$ & $0.36 \mathrm{bc}$ & $0.32 \mathrm{c}$ \\
\hline
\end{tabular}

* in $\mathrm{ml}$ of $\mathrm{NaOH} 0.1 \mathrm{~N} / 100 \mathrm{~g}$ of sample

Table 2. Phytochemicl compounds at different maturity stages in fresh and dried acerola

\begin{tabular}{|l|c|c|c|c|c|c|c|c|}
\hline \multirow{2}{*}{ Constituents } & \multicolumn{4}{|c|}{ Fresh acerola } & \multicolumn{4}{c|}{ Dried acerola } \\
\cline { 2 - 9 } & Green & $\begin{array}{c}\text { Green/ } \\
\text { yellow }\end{array}$ & $\begin{array}{c}\text { Pale } \\
\text { red }\end{array}$ & $\begin{array}{c}\text { Ripe } \\
\text { mature }\end{array}$ & Green & $\begin{array}{c}\text { Green/ } \\
\text { yellow }\end{array}$ & $\begin{array}{c}\text { Pale } \\
\text { red }\end{array}$ & $\begin{array}{c}\text { Ripe } \\
\text { mature }\end{array}$ \\
\hline Vitamin $\mathrm{C} \mathrm{mg} / 100 \mathrm{~g}$ & $1430 \mathrm{~b}$ & $1568.67 \mathrm{a}$ & $1317.33 \mathrm{c}$ & $842.17 \mathrm{~d}$ & $552.47 \mathrm{~b}$ & $582.83 \mathrm{a}$ & $547.07 \mathrm{~b}$ & $366.83 \mathrm{c}$ \\
Polyphenols $\mathrm{mg} / 100 \mathrm{~g}$ & $2752.13 \mathrm{~b}$ & $2953.5 \mathrm{a}$ & $2533.97 \mathrm{c}$ & $2259.99 \mathrm{~d}$ & $2059.42 \mathrm{~b}$ & $2313.18 \mathrm{a}$ & $1967.12 \mathrm{c}$ & $1637.81 \mathrm{~d}$ \\
Flavonoids & $12.5 \mathrm{c}$ & $14.21 \mathrm{a}$ & $13.76 \mathrm{~b}$ & $10.88 \mathrm{~d}$ & $9.18 \mathrm{c}$ & $11.46 \mathrm{a}$ & $10.07 \mathrm{~b}$ & $7.16 \mathrm{~d}$ \\
Carotenoids $\mu / 100 \mathrm{~g}$ & $1010.1 \mathrm{~d}$ & $1226.6 \mathrm{c}$ & $1346.8 \mathrm{~b}$ & $1924 \mathrm{a}$ & $745.6 \mathrm{~d}$ & $801.7 \mathrm{c}$ & $1034.2 \mathrm{~b}$ & $1467.05 \mathrm{a}$ \\
Total anthocyanin $\mathrm{mg} / 100 \mathrm{~g}$ & $2.1 \mathrm{~d}$ & $4.42 \mathrm{c}$ & $7.75 \mathrm{~b}$ & $14.79 \mathrm{a}$ & $1.07 \mathrm{~d}$ & $2.29 \mathrm{c}$ & $4.36 \mathrm{~b}$ & $5.36 \mathrm{a}$ \\
\hline
\end{tabular}

Eleven compounds of phenols were identified in the second stage of mature (green/yellow) for either fresh or dried by HPLC analysis. The detected phenolic compounds were gallic, protochatechuic, catchein, chatechol, chlorogenic, caffeic, syringic, ellagic, ferrulic, coumarine and cinnamic as shown in Table (3) and Figs. (1 and 2). The highest content of phenolic compounds was protocatechuic $34.77 \mathrm{mg} / \mathrm{g}$ then decreased to $27.54 \mathrm{mg} / \mathrm{g}$ after drying under vacuum at $50^{\circ} \mathrm{C}$ followed by ferrulic 10.12 in fresh ripening acerola $\mathrm{mg} / \mathrm{g}$ decreased to 2.19 after drying while catechol and cinnamic had the lowest acerola phenolic compounds recorded $(1.21$ and $0.42 \mathrm{mg} / \mathrm{g}$ ) in fresh acerola and $(0.40$ and $0.18 \mathrm{mg} / \mathrm{g})$ after drying, respectively. These results were agreement with that obtained by Righetto et al (2005) which identified some phenolic compounds such as catechin, gallic
Table 3. Phenolic compounds $\mathrm{mg} / 100 \mathrm{gm}$ of fresh and dried acerola

\begin{tabular}{|l|c|c|}
\hline & $\begin{array}{c}\text { Fresh ac- } \\
\text { erola }\end{array}$ & $\begin{array}{c}\text { Dried } \\
\text { acerola }\end{array}$ \\
\hline Gallic & 3.19 & 1.77 \\
protocatechuic & 34.77 & 27.54 \\
Catchein & 7.26 & 0.98 \\
Catechol & 1.21 & 0.4 \\
Chlorogenic & 5.08 & 3.59 \\
Caffeic & 1.74 & 2.01 \\
Syrngic & 3.46 & 0.81 \\
Ellagic & 8.61 & 4.56 \\
Ferrulic & 10.12 & 2.19 \\
Coumarine & 1.81 & 0.53 \\
Cinnamic & 0.42 & 0.18 \\
\hline
\end{tabular}




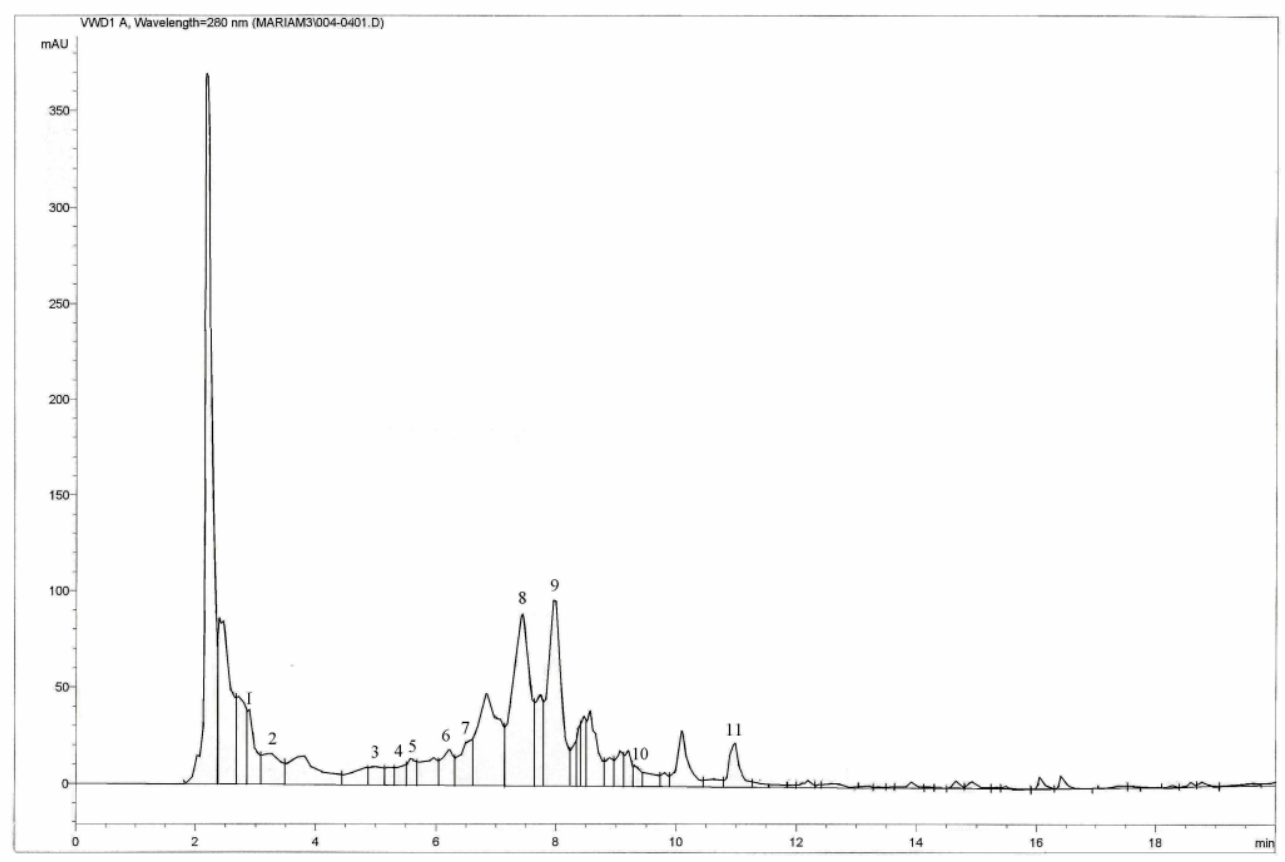

Fig. 1. Chromatogram of phenolic compounds in fresh acerola 1. gallic, 2. protochatechuic, 3. catchein, 4. chatechol, 5. chlorogenic, 6. caffeic, 7. syringic, 8.ellagic, 9. ferrulic, 10. coumarine and 11. cinnamic

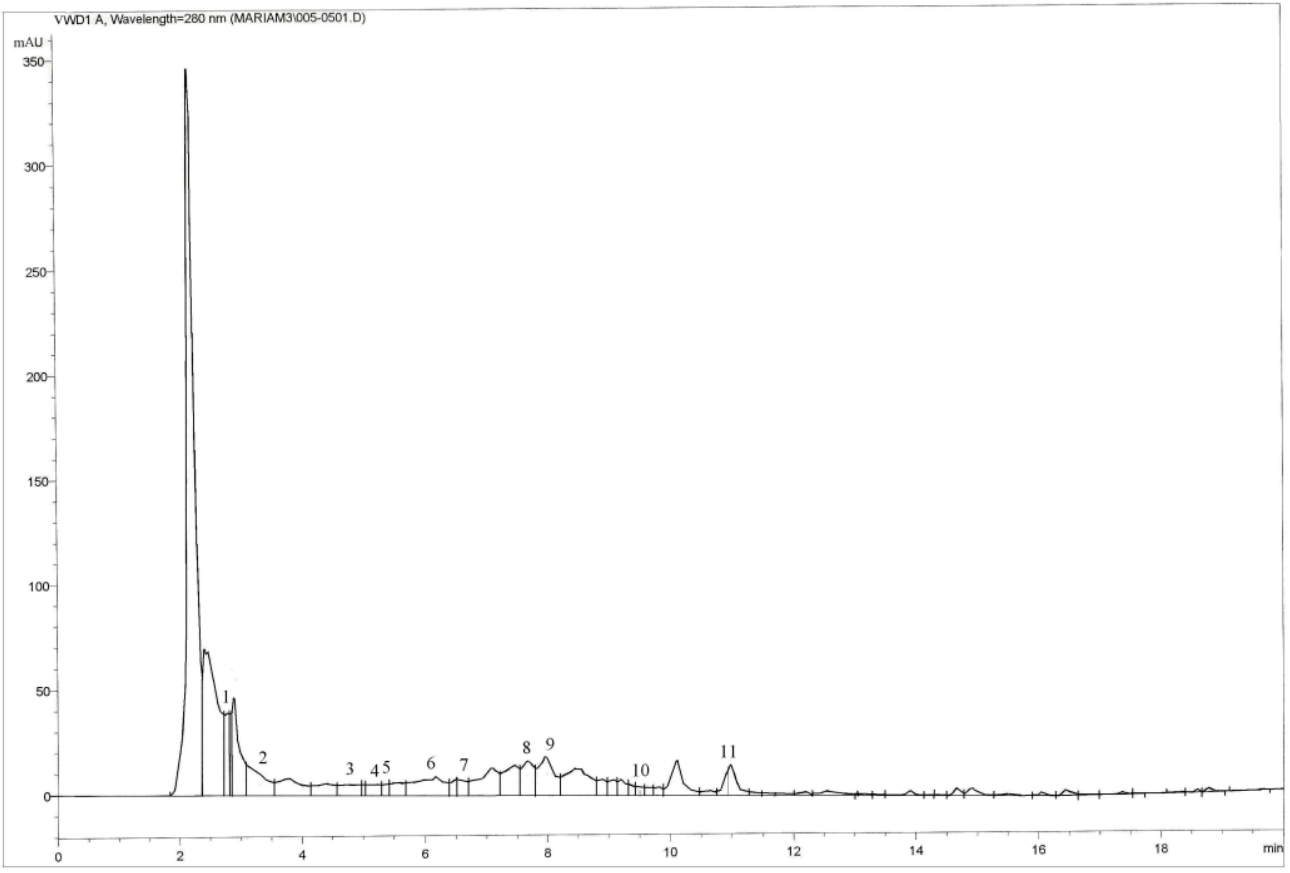

Fig. 2. Chromatogram of phenolic compounds in dried acerola 1. gallic, 2. protochatechuic, 3. catchein, 4. chatechol, 5. chlorogenic, 6.caffeic, 7.syringic, 8.ellagic, 9. ferrulic, 10.coumarine and11.cinnamic 
acid, coumaric acid, syringic acid, caffeic acid and ferrulic acid in prepared immature acerola juice by HPLC analysis.

Results in Table (4). Shows that total antioxidant activity (TAA) of acerola in different maturity stages. One hundred $\mathrm{ml} 80 \%$ methanol concentrations was used to extract $5 \mathrm{gm}$ fresh acerola. After that, 10 to $50 \mu \mathrm{mL}$ were taken to determine the total antioxidant activity (TAA). These results revealed that antioxidant activity of acerola was gradually increased by increasing the extracted concentration. On the other side, the second stage (green/yellow) had the highest percentage of total antioxidant activity was found at $50 \mu \mathrm{mL}$ which was $74.46 \%$, while the lowest activity was obtained in ripe mature stage which recorded $20.75 \%$ of TAA. These results indicating that the antioxidant compounds present in acerola such as ascorbic acid, phenols, flavonoids and anthocyanins with high percentages which acts together as an important role for antioxidant activity. Also, it contains highest antioxidant activity of both gallic and protochatechuic acid and our results correlated with the results obtained by Scherer \& Godoy (2009) which used as a new antioxidant activity index AAI determined by DPPH method and they found the gallic acid was higher value of AAI (27) followed protochatechuic acid (20) and these two compounds may play an important role as strongly antioxidant compounds in acerola fruit.

Sensory evaluation of acerola jam prepared by acerola fruit pulp as will as mixing acerola with fig fruit $1: 1$ and 1:2 (w/w) is illustrated in Table (5). Results revealed that no significant differences in the colour and odor in all prepared jams. While, acerola pulp was mixed with fig fruit $1: 1 \mathrm{w} / \mathrm{w}$ recorded significant increased in taste and texture comparing with other jam samples. Meanwhile, the lowest score was observed in jam prepared by fig fruit. Also, acerola was mixed with fig 1:1 recorded the highest score compared with other prepared jam. At the same time, jam prepared by acerola pulp and acerola mixed with 1:2 fig recorded moderate score while the lowest score was obtained with fig fruit jam. Conclusively, acerola fruit improved the quality of fig jam comparing with fig jam without acerola.

Results in Table (6). Show the content of ascorbic acid, phenolic compounds and antioxidant activity in acerola fruit jam and jam prepared from acerola and mixing with fig fruit 1:1 and 1:2 w/w. Results show that the content of ascorbic acid was increased by increasing the percent of acerola fruit in prepared jam mixed between acerola and fig caused by the high content of ascorbic acid. The contents of ascorbic acid were 286.14, 220.84 and $178.95 \mathrm{mg} / 100 \mathrm{~g}$ in acerola jam, acerola mixed with fig (1:1) and acerola mixed with figs (1:2), respectively, while the lowest content was $3.08 \mathrm{mg} / 100 \mathrm{~g}$ jam in fig fruit jam. Also, phenolic compounds were $109.79 \mathrm{mg} / 100 \mathrm{gm}$ in fig fruit jam and increased to $384.62 \mathrm{mg} / 100 \mathrm{gm}$ with acerola jam. At the same time, it could be noticed that there were a gradually decreased from 346.15 and $283.22 \mathrm{mg} / 100 \mathrm{~g}$ for prepared acerola jam mixed with fig (1:1) and acerola mixed with fig (1:2), respectively. Results indicated also, the highest percent of total antioxidant activity in acerola fruit jam $89.17 \%$ (by extracting with $100 \mathrm{ml}$ methanol $80 \%$ from $5 \mathrm{gm}$ acerola jam), while the lowest percentage was $3.02 \%$ for fig fruit jam.

Table 4. Antioxidant activity (\%) at different maturity stages of fresh acerola

\begin{tabular}{|c|c|c|c|c|}
\hline $\begin{array}{c}\text { Extracted acerola* } \\
\boldsymbol{\mu} \mathbf{m L}\end{array}$ & Green & $\begin{array}{c}\text { Maturity stages } \\
\text { Green/yellow }\end{array}$ & Pale red & Ripe mature \\
\hline 10 & 4.94 & 8.5 & 7.11 & 4.55 \\
20 & 9.49 & 17 & 12.06 & 7.71 \\
30 & 16.6 & 20.95 & 22.6 & 11.6 \\
40 & 24.31 & 44.47 & 34.39 & 16.21 \\
50 & 66.01 & 74.46 & 55.99 & 20.75 \\
\hline
\end{tabular}

* $5 \mathrm{gm}$ fresh acerola extracted by $100 \mathrm{~mL} 80 \%$ methanol 
Table 5. Sensory evauation of jam prepared from acerola fruit and mixed with fig fruit

\begin{tabular}{|l|c|c|c|c|c|}
\hline & Colour & Taste & Odor & Texture & $\begin{array}{c}\text { Over all } \\
\text { acceptability }\end{array}$ \\
\hline Fig fruit & $7.5 \mathrm{a}$ & $7 \mathrm{~b}$ & $7 \mathrm{a}$ & $6.44 \mathrm{~b}$ & $6.83 \mathrm{~b}$ \\
Acerola fruit & $7.66 \mathrm{a}$ & $7.28 \mathrm{ab}$ & $7.61 \mathrm{a}$ & $7.72 \mathrm{a}$ & $7.44 \mathrm{ab}$ \\
Acerola with fig & $7.88 \mathrm{a}$ & $8.17 \mathrm{a}$ & $7.67 \mathrm{a}$ & $8.06 \mathrm{a}$ & $8.28 \mathrm{a}$ \\
$1: 1$ & & & & & $7.61 \mathrm{ab}$ \\
Acerola with fig & $7.94 \mathrm{a}$ & $7.78 \mathrm{ab}$ & $7.39 \mathrm{a}$ & $7.44 \mathrm{ab}$ & \\
\hline \multicolumn{1}{|c|}{$1: 2$} & & & & & \\
\hline
\end{tabular}

Table 6. The content of ascorbic acid, phenolic compounds and antioxidant activity in acerola jam and mixed with fig fruit

\begin{tabular}{|c|c|c|c|c|}
\hline & Fig fruit & Acerola fruit & $\begin{array}{c}\text { Acerola with fig } \\
\mathbf{1 : 1}\end{array}$ & $\begin{array}{c}\text { Acerola with fig } \\
\mathbf{1 : 2}\end{array}$ \\
\hline $\begin{array}{c}\text { Ascrbic acid } \\
\mathrm{mg} / 100 \mathrm{gm}\end{array}$ & $3.08 \mathrm{~d}$ & $286.14 \mathrm{a}$ & $220.84 \mathrm{~b}$ & $178.95 \mathrm{c}$ \\
$\begin{array}{c}\text { Phenolic compounds } \\
\text { mg/100gm }\end{array}$ & $109.79 \mathrm{~d}$ & $384.62 \mathrm{a}$ & $346.15 \mathrm{~b}$ & $283.22 \mathrm{c}$ \\
$\begin{array}{c}\text { Total antioxidant } \\
\text { activity \% }\end{array}$ & 3.02 & 89.17 & 60.43 & 45.28 \\
\hline
\end{tabular}

\section{REFERENCES}

AOAC (1990). Official Methods of Analysis. Association Official Analytical Chemists, Washington, DC, USA.

AOAC (1970). Official Methods of Analysis. Association Official Analytical Chemists, pp. 832-832. Washington, Dc, USA.

Assis, S.A.; D.C. Lima and O.M.M.F. Oliveira (2001). Activity of pectinmethylesterase, pectin content and vitamin $\mathrm{C}$ in acerola fruit at various stages of fruit development, Food Chem., 74: 133-137.

Brand-Williams, W.; M.E. Cuvelier and C. Berset (1995). Use of free radical method to evaluate antioxidant activity. Lebensmittel- Wissenschaft und Technologie, 28: 25 - 30.

Brenes, C.H.; D. Del Pozo-Insfran and S. Talcott (2005). Stability of copigmented anthocyanins and ascorbic acid in a grape juice model system. Journal of Agricultural and Food Chemistry, 53: 49-56.

Clifford, M.N. (1995). Understanding the biological effects of dietary complex phenols and tannins and their implications for the consumer's health and well being. (Report of the European Project FAIR-CT95-0653. European Community Programme for Research, Technological Development and Demonstration in the field of Agriculture and Fisheries).

Colin, F. and B. Peter (1980). Anthocyanins in: Development in Food Colors pp.115-143. Edited by J. Walford- Applied Science, Publishers LTD, London.

Garzon, G.A. and R.E. Wrolstad (2002). Comparison of the stability of pelargonidin-based anthocyanins in strawberry juice and concentrate. Journal Food Science, 67: 1288-1299. 
Goupy, P.; M. Hugues; P. Boivin and M.J. Amoit (1999). Antioxidant composition and activity of barley (Hordeum vulgare) and malt extracts and of isolated phenolic compounds. J. Sci. Food Agric., 79: 1625-1634.

Hanamura, T.; T. Hagiwara and H. Kawagishi (2005). Strustural and functional characterization of polyphenols isolated from acerola (Malpighia emarginata DC.) fruit. Bioscience Biotechnology Biochemistry, 69(2): 280-286.

Hertog, M.G.L.; D. Kromhout; C. Aravanis; H. Blackburn; R. Buzina; F. Fidanza; S. Giampaoli; A. Jansen; A. Menotti; S. Nedeljkove; M. Pekkarinen; B.S. Simic; H. Toshima; E.J.M. Feskens; P.C.H. Hollman and M.R. Katan (1995). Flavonoid intake and long-term and risk of coronary heart disease and cancer risk in the Seven Countries study. Archives of Internal. Medicine, 155: 381-386.

Lima, V.L.A.G.; E.A. Melo; M.I.S. Maciel; F.G. Prazeres; R.S. Musser and D.E.S. Lima (2005). Total phenolic and carotenoid contents in acerola genotypes harvested at three ripening stages, Food Chem., 90: 565-568.

Mezadri, T.; A. Perez-Galvez and D. HorneroMendez (2005). Carotenoid pigments in acerola fruits (Malpighia emarginata DC.) and derived products. European Food Research Technology, 220: 63-69.

Mezadri, T.; D. Villano; M.S. Fernandez-Pachon; M.C. Garcia-Parrilla and A.M. Troncoso (2008). Antioxidant compounds and antioxidant activity in acerola(Malpighia emarginata DC.) fruits and derivatives. Journal of Food Composition and Analysis, 21: 282- 290

Mezquita, P.C. and Y.G. Vigoa (2000). The acerola: marginal fruit from America with a high level of ascorbic acid. Alimentaria 37: 113-125.
Righetto, A.M.; F.M. Netto and F. Carraro (2005). Chemical Composition and Antioxidant Activity of Juices from Mature and Immature Acerola (Malpighia emarginata DC). Food Science and Technology International, 11(4): 315-321.

Scherer, R. and H.T. Godoy (2009). Antioxidant activity index (AAI) by the 2,2-diphenyl-1picrylhydrazyl method. Food Chem., 112: 654658.

Seeram, N. and M. Nair (2002). Inhibition of lipid peroxidation and structureactivity-related studies of the dietary constituents anthocyanins, anthocyanidins, and catechins. Journal of Agricultural and Food Chemistry, 50: 5308-5312.

Shelukhina, N.P. and L.G. Fedichkina (1994). A rapid method for determination of pectic substances. Acta Bot. Neerl., 2: 63-73.

Vendramini, A.L. and L.C. Trugo (2000). Chemical composition of acerola fruit (Malpighia punicifolia L.) at three stages of maturity. Food Chemistry, 71: 195-198.

Vera de Rosso, V.; S. Hillebrand; E.C. Montilla; F.O. Bobbio; P. Winterhalter and A.Z. Mercadantea (2008). Determination of anthocyanins from acerola (Malpighia emarginata DC.) and acai (Euterpe oleracea Mart.) by HPLC-PDAMS/MS. Journal of Food Composition and Analysis, 21: 291-299.

WHO (2003). Diet, Nutrition and the Prevention of Chronic Diseases. Technical Report Series (p. 149). World Health Organization, Geneva, 916pp. Zhang, D. and Y. Hamauzu (2004). Phenolics, ascorbic acid, carotenoids and antioxidant activity of broccoli and their changes during conventional and microwave cooking. Food Chem., 88: 503509.

Zhuang, X.P.; Y.Y. Lu, and G.S. Yang (1992) Extraction and determination of flavonoid in ginkgo. Chinese Herbal Medicine, 23: 122-124. 